\title{
ッグミの飛び立ち距離に影響する要因
}

\author{
松岡 茂* \\ 農林水産省農業研究センター・鳥害研究室
}

\section{Factors affecting the flight distance of the Dusky Thrush Turdus naumanni}

\author{
Shigeru MATSUOKA* \\ Bird Control Laboratory, National Agriculture Research Center, \\ Ministry of Agriculture, Forestry and Fisheries, \\ Tsukuba City, Ibaraki 305
}

\begin{abstract}
Flight distances were measured in the Dusky Thrush, Turdus naumanni, in winter. Predictive models relating flight distance of the thrush to environmental variables were developed and tested using stepwise multiple regression. The models, based on analyses of possible independent variables collected in 1984 and 1985 , accounted for $54 \%$ and $82 \%$ of the variation in flight distance, respectively. The most important independent variables were location of the thrush (whether it was within 10 meters from the nearest shelter belt or not) and snow depth in 1984, and distances from the thrush to the nearest shelter belt and perch height in 1985 . Longer flight distances were recorded further away from shelter belt. Snow fall made the flight distance shorter. Based on the multiple regression model in 1985, I predicted flight distance of thrushes and the time until they flew off for each distance from the shelter belt and showed that a thrush would stay a longer time before it flew off near shelter belts.
\end{abstract}

Key Words: Flight distance, Multiple regression model, Turdus naumanni.

地上で採食している鳥に地上性の捕食者が接近していった場合，鳥は明らかに捕食者の 接近に気づいているにあかかわらず，ある一定の距離までは接近を許容する．最終的に鳥 は飛び立ってしまうが, そのときの鳥と捕食者との距離を飛び立ち距離 flight distance という (HEDIGER 1950). 飛び立ち距離の変異に影響する要因として, 群れサイズ（群 れを構成する個体数) や鳥の齢（DHINDSA \& BOAG 1989）などをあげることができる. たとえば，地上で採食しているチョウショウバト Geopelia striata の3 羽以上の群れや ヒヨドリ Hypsipetes amaurotis の群れでは, 群れサイズの増加にとあない飛び立ち距 離が増加する傾向が認められている (GREIG-SMITH 1981, 松岡 1994a). 著者は, ヒヨ ドリの飛び立ち距離の計測時に, ほかの地上採食を行なう種についても飛び立ち距離の測

* 現所属: 農林水産省森林総合研究所北海道支所 - 鳥獣研究室. Present address : Wildlife Management Laboratory, Hokkaido Research Center, Forestry and Forest Products Research Institute, Ministry of Agriculture, Forestry and Fisheries, Toyohira-ku, Sapporo 062. 
定を試みた．その際, 周辺の環境条件によってこれら鳥類の飛び立ち距離に大きな変異が あるように思えたので, 新たにこれらの鳥類についてデータの収集を行なった.

この論文では，比較的多くのサンプルを収集できたッグミ Turdus naumanni につい ての分析結果を報告する. ツグミは，茨城県つくば市では 11 月初旬から 4 月下旬頃まで 出現する冬鳥で（松岡 1984）, 農耕地では裸地や芝生畑など見通しのよい地上で採食する ことが多い，そのため，飛び立ち距離を測定する材料として適している．また，ほとんど の個体が単独で採食しているので, 群れサイズの要因については考慮しなくてょい.さら に，地上採食の鳥類は積雪によって物理的に採食場所が制限されると考えられるが，ッグ ミもその例にもれない.つくば市ではまれな $20 \mathrm{~cm}$ を越える積雪によってッグミの採食場 所や越冬個体数に大きな影響が認められている（松岡 1984）.このような気象条件の変異 やッグミの採食場所に関する変異が, 彼らの飛び立ち距離の変異とどの様に関係している か，またどのような要因が飛び立ち距離にもっとも大きく影響しているかを明らかにする ことがこの論文の目的である.

\section{調查地及び方法}

ッグミの飛び立ち距離の測定は, 茨城県つくば市にある農林水産省農業研究センターお よび隣接する農業環境技術研究所のほ場で, 1984 年は 2 月 2 日から 3 月 2 日（時間は 8 時 から 10 時 30 分）まで，1985 年は 2 月 12 日から 4 月 5 日（時間は 8 時から 15 時）まで行 なった．飛び立ち距離は次のように測定した．1. ほ場で採食しているッグミを探しだし， 測定する個体を決定する．他のッグミの存在の影響を除くため，少なくとも $100 \mathrm{~m}$ 以内 に同種他個体やヒョドリの群れがいないことを確認した. 1985 年には，防風林内の樹上 のッグミも測定の対象とした. 2. ツグミに向かって時速 $2 \mathrm{~km}$ 位でゆっくり歩いて行く.

3. ツグミが飛び去った時のッグミと観察者との間の距離を歩測により $\mathrm{m}$ 単位で計測した あのを, 飛び立ち距離とする．樹上のッグミの場合には，観察者からッグミがとまってい たところの直下までの距離を測定し，この值とッグミがとまっていた場所の地上高から計 算により求めた． 4. ツグミが飛び立って再び降りた場所まで目視により追跡でき，かつ その降り立った場所が1の条件を満たしている場合には, さらに連続して 2,3 を繰り返し て，デー夕を収集した．最高で 3 回連続して飛び立ち距離を測定することができた，飛び 立ち距離の測定後に, 測定日時, 同一個体についての測定の順番, ッグミが採食していた 環境の記載を行なった．ここで環境については, 1984 年には, ッグミが防風林の縁から $10 \mathrm{~m}$ 以内にいたかあるいはそれ以上離れたほ場にいたか，および積雪深（cm）を計測し た. さらに, 分析にあたっては, 飛び立ち距離の測定時の気温 $\left({ }^{\circ} \mathrm{C}\right)$, 相対湿度 (\%), 風 速 $(\mathrm{m} / \mathrm{sec})$, 雲量 $(0-10)$ の気象デー夕を加えた. これらの気象デー夕は, 農業環境技 術研究所で測定されたものを用いた.

1985 年の環境要因は, 1984 年の分析結果をふまえて, 採食していたッグミからあっと あ近い防風林縁までの距離（防風林内にいた場合は $0 \mathrm{~m}$ とする）, ッグミからすっとも近 くにある防風林や林の平均樹高 $(\mathrm{m})$, ッグミがいた場所の地上からの高さ（地上の場合 を $0 \mathrm{~m}$ とする), および雲量を野外で計測した。 ただし, 気温, 風速については農業環境 技術研究所での測定データを使用した。また, 飛び立ち距離の測定は著者が一人で行ない, 


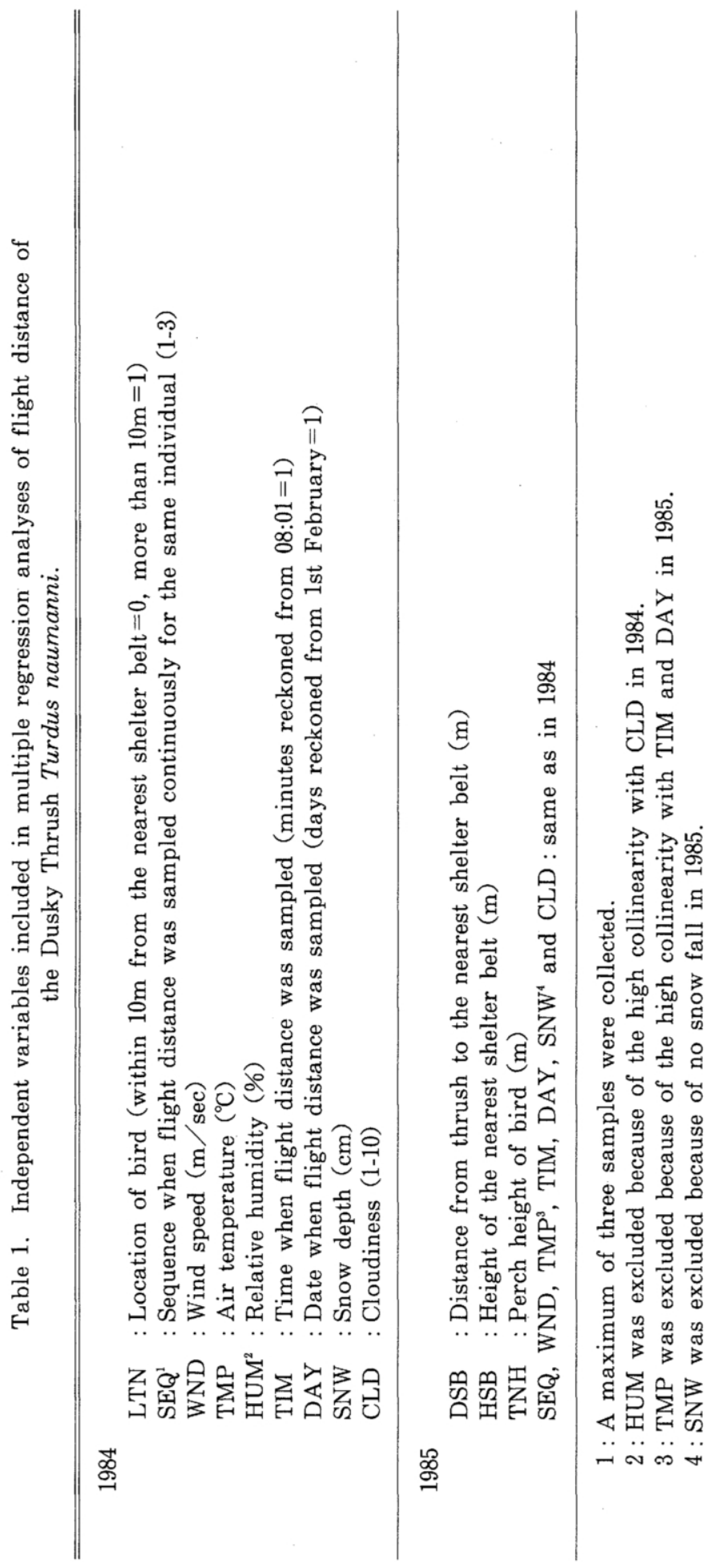


測定時には常に同じ服装を着用した.

データの分析は, ッグミの飛び立ち距離を従属変数とし, ッグミがいた周辺の環境条件 や気象デー夕を説明変数 (Table 1) とする重回帰モデルによって行なった. このときモ デルの誤差項については, 互いに独立で平均 0 , 分散 $\sigma^{2}$ の正規分布を仮定した. 変数選 択は, 増減法により行なった. 変数の取込と除去の基準は, ともに有意レベル 0.15 で行 なった. モデルに取込む説明变数については, 測定日は 2 月 1 日を 1 と日単位で, 測定 時間については午前8時1分を 1 と分単位で表わした. 1984 年のッグミの採食位置は, 防 風林の縁から $10 \mathrm{~m}$ 以内にいた場合には 0 を，それ以外は1をとるダミー变数とした.

また, 1985 年の重回㷌式を利用してッグミの飛び立ち距離を予測し，それを基に防風 林からの距離別にッグミが飛び立つまでの時間を数值実験により求めた．最初に, ッグミ は地上だけにいると仮定して（TNH=0), 防風林からの距離別に飛び立ち距離を求めた. このとき, 防風林の高さは, 飛び立ち距離の測定の際に記録した高さの平均值（6.1）と 標準偏差 (2.0) を用い, 飛び立ち距離の変異を求めた. 次に, ッグミが地上に降り立っ た瞬間に 100 200 m 離れたランダムな地点から人間がッグミに $2 \mathrm{~km} / \mathrm{h}$ の速度で近づい ていくという条件で, ッグミが飛び立つまでの時間を求めた. 計算は, 100 200 の一様 乱数之防風林の高さの分布に従う乱数から求めた飛び立ち距離の差を求め, 歩く速さで割っ て飛び立つまでの時間を求めた。これを防風林からの距離別にそれぞれ 100 回繰り返し, その平均と標準偏差を求めた.

\section{結果}

1） 1984 年のデータの分析結果

1984 年に収集した 150 例の飛び立ち距離のデータについて, 説明変数間の単相関係数 (Kendall $\tau$ ) を求めた. それらの間では, いくつか高い相関が認められた. その中であ 相対湿度については, 他の説明変数との間に高い相関が多く, とくに温度とは負の（一 $0.46, P<0.01)$ また雲量とは正の相関 $(0.42, P<0.01)$ が高かった. これらの関係は, 相対湿度について通常予測されるすのである. そこで, 多重共線性に関する分析（分散増 加要因評価指数 VIF に関する分析）を行なったところ, 相対湿度, 雲量の2変数に共線 性の傾向がみられた. 共線性のある変数をともにモデルに含めると互いのパラメー夕の推 定值が大きく変わる傾向があるため, どちらか一方の变数を用いることが推奨されている (SASインスティチュートジャパン 1992). 説明変数間の単相関係数と多重共線性に関 する分析結果を考慮して，1984 年の分析については相対湿度を説明变数のリストから除 いた.

増減法による選択の過程では, 最初のステップで, ッグミの採食位置に関する変数

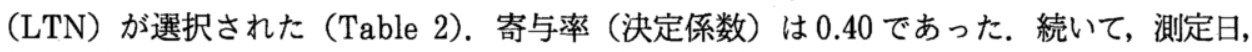
積雪深などの変数が選択され, 最終的には測定の順番と雲量の $2 つ$ 変数を除く 6 変数が 重回帰モデルに取り込まれた. 重回帰モデルは統計学的に有意であったが, このモデル全 体の寄与率は 0.54 とそれほど高くなく, 従属变数のばらつきの半分程度しか説明してい ない. Table 2 には, 重回帰式の偏回帰係数, 標準偏回㷌係数む示した. 標準偏回㷌係 数の值から, ッグミの飛び立ち距離への寄与の程度の最大のものは, ッグミの採食場所に 
Table 2. Multiple regression analysis of flight distance (data collected in 1984)

2-1 Summary of stepwise procedure for dependent variable

\begin{tabular}{ccccccc}
\hline \hline \multirow{2}{*}{ Step } & \multicolumn{2}{c}{ Variable } & Partial & Model & & \\
\cline { 2 - 4 } & entered & removed & $\mathrm{R}^{2}$ & $\begin{array}{c}\mathrm{R}^{2} \\
\text { F value }\end{array}$ & Prob $>$ F \\
\hline 1 & LTN & - & 0.396 & 0.396 & 97.145 & 0.0001 \\
2 & DAY & - & 0.059 & 0.456 & 16.049 & 0.0001 \\
3 & SNW & - & 0.038 & 0.494 & 11.009 & 0.0011 \\
4 & WND & - & 0.012 & 0.506 & 3.610 & 0.0594 \\
5 & TMP & - & 0.010 & 0.516 & 3.010 & 0.0849 \\
6 & TIM & - & 0.027 & 0.544 & 8.514 & 0.0041 \\
\hline
\end{tabular}

2-2 Analysis of variance

\begin{tabular}{rrrrrc}
\hline \hline Source & DF & $\begin{array}{c}\text { Sum of } \\
\text { squares }\end{array}$ & $\begin{array}{c}\text { Mean } \\
\text { square }\end{array}$ & F value & Prob $>$ F \\
\hline Model & 6 & 5607.793 & 934.632 & 28.370 & 0.0001 \\
Error & 143 & 4711.040 & 32.944 & & \\
Total & 149 & 10318.833 & & & \\
\hline
\end{tabular}

2-3 Parameter estimates

\begin{tabular}{lcccccr}
\hline \hline Variable & DF & $\begin{array}{c}\text { Parameter } \\
\text { estimate }\end{array}$ & $\begin{array}{c}\text { Standard } \\
\text { error }\end{array}$ & $\begin{array}{c}\text { T for } \mathrm{H} 0: \\
\text { parameter }=0\end{array}$ & Prob $>|\mathrm{T}|$ & $\begin{array}{c}\text { Standardized } \\
\text { estimate }\end{array}$ \\
\hline INTERCEPT & 1 & 11.836 & 2.337 & 5.063 & 0.0001 & 0.0000 \\
LTN & 1 & 10.635 & 1.082 & 9.826 & 0.0001 & 0.5670 \\
WND & 1 & -0.783 & 0.295 & -2.650 & 0.0090 & -0.1670 \\
TMP & 1 & -0.796 & 0.270 & -2.945 & 0.0038 & -0.1904 \\
TIM & 1 & 0.075 & 0.026 & 2.918 & 0.0041 & 0.1945 \\
DAY & 1 & 0.185 & 0.055 & 3.359 & 0.0010 & 0.1958 \\
SNW & 1 & -0.633 & 0.159 & -3.983 & 0.0001 & -0.2486 \\
\hline
\end{tabular}

関する変数であることが明らかである.これは, 防風林から $10 \mathrm{~m}$ 以上離れたところで採 食しているッグミの飛び立ち距離が大きいことを示している. 積雪深の值がこれに続くが, 負の值であり, 積雪深の増加につれ飛び立ち距離が短くなるように寄与している. その他, 風速, 温度では負の, 測定日と測定時間は正の寄与をしているが, これらの寄与の程度は 比較的小さいむのであった.

2) 1985 年のデータの分析結果

1985 年には, 136 例の飛び立ち距離に関するデータを収集した。 しかし，気象データの 欠測値のため, 分析には 128 例を使用した. 1985 年のデータについても変数間の単相関 係数 (Kendall $\tau$ ) を求めた. 1984 年の分析結果を参考にして, 相対湿度については最 初から説明变数のリストから除いた. 1985 年には積雪がみられなかったので, 積雪量に ついても説明変数のリストから省いた．また，1985年は前年に比べてデータを収集した 時間の範囲も大きく，また測定日の範囲も 2 月から 4 月初旬までと大きくなっている. そ 
Table 3. Multiple regression analysis of flight distance (data collected in 1985)

3-1 Summary of stepwise procedure for dependent variable

\begin{tabular}{|c|c|c|c|c|c|c|}
\hline \multirow[b]{2}{*}{ Step } & \multicolumn{2}{|c|}{ Variable } & \multirow{2}{*}{$\begin{array}{c}\text { Partial } \\
\mathrm{R}^{2}\end{array}$} & \multirow{2}{*}{$\begin{array}{c}\text { Model } \\
\mathrm{R}^{2}\end{array}$} & \multirow[b]{2}{*}{$\mathrm{F}$ value } & \multirow[b]{2}{*}{ Prob $>F$} \\
\hline & entered & removed & & & & \\
\hline 1 & DSB & - & 0.718 & 0.718 & 59.655 & 0.0001 \\
\hline 2 & $\mathrm{TNH}$ & - & 0.088 & 0.805 & 4.576 & 0.0001 \\
\hline 3 & HSB & - & 0.011 & 0.816 & -0.614 & 0.0072 \\
\hline
\end{tabular}

3-2 Analysis of variance

\begin{tabular}{lrrrrc}
\hline \hline Source & DF & $\begin{array}{c}\text { Sum of } \\
\text { squares }\end{array}$ & $\begin{array}{c}\text { Mean } \\
\text { square }\end{array}$ & F value & Prob $>$ F \\
\hline Model & 3 & 23094.932 & 7698.311 & 183.801 & 0.0001 \\
Error & 124 & 5193.620 & 41.884 & & \\
Total & 127 & 28288.551 & & & \\
\hline
\end{tabular}

3-3 Parameter estimates

\begin{tabular}{ccrcccc}
\hline \hline Variable & DF & $\begin{array}{c}\text { Parameter } \\
\text { estimate }\end{array}$ & $\begin{array}{c}\text { Standard } \\
\text { error }\end{array}$ & $\begin{array}{c}\text { T for } \mathrm{H} 0: \\
\text { parameter }=0\end{array}$ & Prob $>|\mathrm{T}|$ & $\begin{array}{c}\text { Standardized } \\
\text { estimate }\end{array}$ \\
\hline INTERCEPT & 1 & 27.726 & 1.858 & 14.925 & 0.0001 & 0.0000 \\
DSB & 1 & 0.381 & 0.023 & 16.440 & 0.0001 & 0.7265 \\
HSB & 1 & -0.837 & 0.306 & -2.733 & 0.0072 & -0.1125 \\
TNH & 1 & -2.017 & 0.322 & -6.259 & 0.0001 & -0.2874 \\
\hline
\end{tabular}

のため温度については, 測定時間 $(0.55, P<0.01)$ や測定日 $(0.46, P<0.01)$ との相関 がとくに顕著であった. 1984 年と同様に多重共線性に関する分析を行ない, その結果を 参考にして, 1985 年の分析からは温度変数を説明変数から除いた.

変数選択では, 最初にッグミからあっとも近い防風林までの距離が取り込まれた. 寄与 率は, 0.72 であった. ついで, ッグミのいた場所の高さ, そして防風林の高さが取り込 まれて, 変数選択を終了した（Table 3). 3 つの説明変数を取り込んだ後の寄与率は, 0.82 と高かった. 標準偏回帰係数の值から, ツグミからあっとも近い防風林までの距離 に関する变数の寄与の程度が最大であった（Table 3). この変数の偏回帰係数の符号は 正であり, 防風林から離れた場所にいるほどッグミの飛び立ち距離は大きくなることを示 している. ついで, ッグミのいた場所の高さの寄与が大きく, これはとまっていた場所の 高さが高いほど飛び立ち距離が小さくなるように寄与した.この 2 つの変数に比較して, 防風林の高さの寄与の程度は小さかったが, 防風林の高さが高いほど飛び立ち距離が短く なるように寄与した.

3）ツグミが飛び立つまでの時間の予測

Fig.1 に, 1985 年の重回帰式から予測したツグミの飛び立ち距離およびランダムな地 点から人間が近づいていったときにッグミが飛び立つまでの時間を示した. 飛び立ち距離 

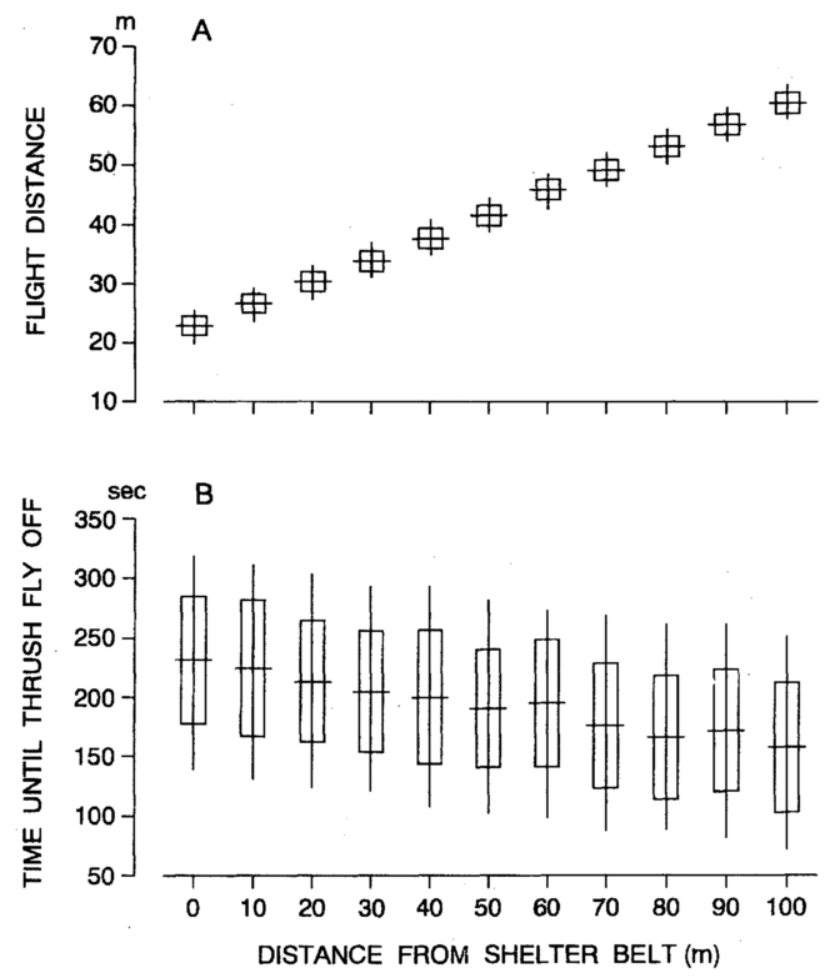

Fig. 1. A : flight distance of the Dusky Thrush predicted from the regression model in 1985 (calculated as $\mathrm{TNH}=0$ ). B : time until thrush fly off (calculated under the condition that a man approaches the thrush from a random point ranging from $100-200 \mathrm{~m}$ at a speed of $2 \mathrm{~km} / \mathrm{h}$ ). Horizontal bar, box, and vertical bar show mean, $\pm 1 S D$, and range, respectively.

は, 防風林の高さのばらつきによる変異がみられるものの, 防風林から離れるにしたがっ て増加する傾向をみせている．ランダムな距離から人間が近づいていったときに飛び立つ までの平均時間は, 飛び立ち距離とは逆に防風林に近いほど長くなっている. また, 防風 林の際にいるッグミと防風林から $100 \mathrm{~m}$ 離れたところにいるッグミの飛び立つまでの平 均時間の差は, 約 72 秒であった.

\section{議論}

1984 年のデー夕を基にした増減法による変数選択では, 6つの変数を取り込んだにもか かわらず, 飛び立ち距離の変動のうちの $54 \%$ しか説明できず, 当てはまりのよいモデル にならなかった. ツグミの位置に関する変数をのぞく他の変数は, 測定日時や気象に関す るあのであるが，それぞれの寄与率は $6 \%$ 以下と小さいあのであった．気象要因につい ては, 風速や温度の変異が森林性の鳥類の採食生態や群れの構成に大きな影響を与えてい るという報告がある. GRUBB（1975）は, 森林性の鳥類の採食場所について, 風が強く気 温の低いときには一般に採食場所の高さが低いほうに移り, 採食場所（幹や枝）の太さは 
より太いほうへ移ることを示した. また, GRUBB（1987）は, 気象条件によって, 単独 での採食, 同一種の群での採食, 混群での採食の割合が変化することも明かにしたが, 餌 条件がよければ気象条件の影響はより少なくなると述べている. 彼は, こうした行動の変 化が温度の低下や風速の増加による代謝率の増加とそれにともなう食物要求量の増大に関 係して起こっていると考えている．このような気象条件の影響は, ツグミにもそのままあ てはまると思われる．気温が低く風速が大きいほど，食物要求量が増大し，ッグミは食物 の獲得のために余分な時間を費やさなければならなくなる．その余分な時間をつくるため の一つの方法は, 捕食者が近づいてきたときに逃げるタイミングを遅らせることである. そのため, ッグミは捕食者の接近をより許容するようになるという予測ができる. 今回の 結果は, 風速, 温度の偏回帰係数はとむにマイナスであり, 風速については予測と一致し た. いっぽう, 気温についてはまったく逆の結果になったが, その理由は不明である. 気 象条件や測定日時に関する変数については, 寄与の程度が比較的小さかったこと, また 1985 年のモデルにはそれらのいずれもが取り込まれなかったことなどから，ッグミの飛 び立ち距離の変異を考える際にはそれほど重要な要因とはなっていないと考えられる.

ただし, 積雪深については, 現在までの報告の多くが鳥類に対する影響の大きさを指摘 している. 1984 年のモデルでも, 積雪深はツグミの位置に関する変数に続いて寄与の程 度が大きな变数であった． 積雪は, 地上で採食することの多い鳥類にとっては採食場所の 制限につながる. そのため, これらの鳥類については積雪深の増加にとあなう越冬数の減 少 (松岡 1971, 1984, 石城ら 1973, 藤巻 1980) や体重の減少 (藤田 1993 など), 採食 する餌内容の変化（松岡 1977, MATSUOKA \& KOJIMA 1979）などが認められている. 積雪が採食場所を制限し，そのためッグミは適当な採食場所に長くとどまって採食を続け る必要があるという点から, 飛び立ち距離は積雪の増加にとあなって隇少するという予測 ができる．積雪深の偏回帰係数の符号はマイナスであり，この予測と一致した．

1985 年の重回帰モデルは, ッグミがいた場所に関する 3 つの変数を取り込んだだけで 寄与率が $82 \%$ となり，かなり当てはまりのよいモデルとなった. 1984 年の結果と共通し ているのは, ッグミと防風林との距離に関する変数の寄与が大きいことである. 鳥類では, 捕食者が現われたときや追われたときに，近くの樹のしげみや薮などに逃げ込むことが多 い(MORSE 1973, MATSUOKA 1980). また, そのような場所が近くにあるかどうかによっ て行動や社会関係に大きな違いが認められている。たとえば，メキシコユキヒメドリ

Junco phaeonotus やカササギ Pica pica では逃げ込める場所から離れるほど周囲を監 視する時間の割合を多くしたり，逆に近いところでは監視時間を短かくするなど行動を变 化させている (CARACO et al. 1980, DiAZ \& ASENSIO 1991). また, SCHNEIDER (1984) は, ノドジロシトド Zonotrichia albicollis で優位な個体ほど逃げ込める場所の近くで 採食することを明らかにしている．いっぽう，そうした林やしげみが捕食者の隠れ場所に あなっている場合があり（CALDWELL 1986）, 鳥達の採食場所はこの2つの要因のトレー ドオフによって決定されているという報告あある（LIMA et al. 1987）。地上の捕食者が 近づいてくるような場合には, 防風林は明らかに逃げ場所としての重要性が高いと思われ る. 防風林の中でのとまり場所の高さが高いほど, 地上の捕食者からは安全と考えられる が，そうした場所にとまっているッグミの飛び立ち距離が短くなるという今回の結果む上 述のことを支持している. ツグミからもっとも近い防風林の高さが高いほど飛び立ち距離 
が短くなる点については, 高いほど逃げ場所としての価値が高くなるため捕食者の接近を より許容するようになるという解釈が可能である. いっぽう, 同じ位置からみた場合防風 林の高さが高いほどッグミは防風林までの距離を近いと感じているのではないかという解 釈すできる. 地上での採食では, 地形の凹凸や作物などに遮られて防風林までの距離を正 確に判断できないため, 防風林の最高点を見上げた角度（仰角）によって防風林までの距 離を判断しているのではないだろうか. しかし, ッグミも両眼視しているはずであり, 仰 角だけで遠近を判断しているとも思われない，防風林の高さの影響については，さらに検 討を要する.

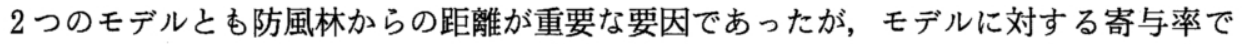
は大きく異なっていた. この変数は, 1984 年の分析では, 0,1 のダミー変数としたのに 対し，1985 年の分析では，ッグミと防風林との距離をとった. これが 1985 年のモデルの あてはまりの良さを高めている原因と考えられる.このことは, 同じ要因をモデルに含め る場合でも, データの計測精度によってモデルの予測性に大きく影響することを示してい る.

以上では, 変数選択による重回帰分析から, 飛び立ち距離に関係する要因を明らかにし ようとした. しかし, 重回帰モデルは, ある一つの変数をいくつかの变数の関数として表 わすあのであり, 本来予測や制御に利用されることが多かった. 農林業の分野では, 害虫 やノネズミの発生予察等に応用されている（是永ら 1981, 中田ら 1985).ここでは, 防風林からの距離によるッグミの飛び立ち距離を予測し, ついでランダムな地点から地上 性の捕食者が近づいてきたときの採食時間を計算により求めた. その結果は, 防風林の近 くでは, 飛び立つまでの時間が長いというあのであった. これを, 単位時間当りの採食量 が一定であるという条件で, ほ場で採食している鳥にあてはめると, 防風林の近くでは採 食量が多いという結果を得る.この条件の基では, 採食量の傾きはッグミが飛び立つまで の時間の傾きと同じになる，しかし，上に述べたような逃げ場所に近いところでの監視時 間の減少などを考慮すると, 防風林の近くでの採食量はさらに大きくなるのに対し, 防風 林から離れたところではより少なくなるものと予想される。ッグミは日本ではスズメやカ ラスに比べて農作物の加害種として重要視されていない（農林水産省農産園芸局植物防疫 課 1975, 1984). イチゴや冬野菜で軽微な被害が報告されているだけであるが, 上述の 点を農作物の被害と関連させると, 単純に考えても, 林縁部での採食時間の大きいことか ら林縁部での農作物に被害が多いことが予測できる. おそらくこの現象は他の鳥にああて はまると考えられる，たとえば，ヒヨドリによってキャベツが害を受けたほ場での被害調 查によれば，防風林近くでの害が多いことが明らかにされている（松岡 1994b). しか し, 実際の被害率は, 上に述べた要因の他にもさまざまな要因によって影響を受けている と考えられるので, 被害率の推定にはそれらの要因の解析が必要であろう.

気象データの利用にあたっては, 農業環境技術研究所気候資源研究室の横沢正幸氏に便宜を計って いただいた，農業研究センター鳥害研究室の中村和雄室長には論文を校閲していただいた．また，森 林総合研究所昆虫管理研究室の Dr. Simon Lawson は英文を校閲してくださった. これらの方々 に感謝の意を表する．また，分析には農林水産省研究計算センターに導入されている S A S 統計パッ ケージを用いた. 


\section{和 文 摘 要}

ッグミの飛び立ち距離の変異に影響する要因を明らかにするため, ッグミの飛び立ち距離を測定し, またツグミがいた場所に関するデー夕を収集した，後に，気象デー夕も加えて，重回帰モデルによる 分析を行なった. 1984 年のデー夕に関する分析では，6つの変数がとりこまれ，モデル全体の寄与率 は 0.54 であった. ツグミの飛び立ち距離への寄与の程度の最大のものは, ッグミの採食場所に関す る变数であった。 ついで積雪深の寄与が大きく, 積雪深の増加につれ飛び立ち距離が短くなるという

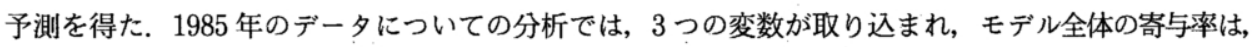
0.82 と高かった．モデルに対する寄与率があっとも高かった変数は, ッグミから防風林までの距離 で, 防風林から離れるほど飛び立ち距離が増加した．ついで, ッグミのとまり場所の高さに関する変 数の寄与の程度が高く, 高いところにとまっているッグミの飛び立ち距離は短くなった. 1985 年の 重回帰式から, 防風林からの距離別にッグミの飛び立ち距離を予測し, さらにランダムな地点から接 近した場合にッグミが飛び立つまでの時間を求めたところ, 防風林に近いところにいるッグミほど, 飛び立つまでに長い時間がかかった.

\section{引用 文 献}

Caldwell, G.S., 1986. Predation as a selective force on foraging herons:effects of plumage color and flocking. Auk 103: 494-505.

Caraco, T., Martindale, S. \& Puluiam, H.R. 1980. Avian time budgets and distance to cover. Auk 97: 872-875.

DHINDSA, M.S. \& BOAG, D.A., 1989. Influence of age on the flushing distance of marked and unmarked black-billed magpies. Ornis Scand. 20: 76-79.

DiAZ, J.D. \& AsENSIO, B., 1991. Effects of group size and distance to protective cover on the vigilance behavior of black-billed magpies Pica pica. Bird Study 38: 38-41.

藤巻裕蔵, 1980. 北海道十勝地方の鳥類. 1. 新得山とその付近の鳥類. 山階鳥研報 12: 40-52.

藤田薰, 1993. シジュウカラの冬期の体重変化. Strix 12: 73-79.

GREIG-SMith, P.W., 1981. Responses to disturbance in relation to flock size in foraging groups of barred ground doves Geopelia striata. Ibis 123: 103-106.

GRUBB, T.C., Jr., 1975. Weather-dependent foraging behavior of some birds wintering in a deciduous woodland. Condor 77: 175-182,

GRUBB, T.C., Jr., 1987. Changes in the flocking behaviour of wintering English titmice with time, weather and supplementary food. Anim.Behav. 35: 794-806.

HEDIGER, H., 1950. Wildanimals in captivity: an outline of the biology of zoological gardens. London, Butterworth Scientific Publications (WILSON 1975 による).

石城謙吉・松岡 茂・小川厳, 1973. 北海道大学苫小牧地方演習林の鳥類相その 2. 北大演習林研報 30: $55-68$.

是永龍二・広崎昭太・塩見正衛, 1981. 重回㷌分析によるヤノネカイガラムシ雌成虫寄生数の予察 (第2報). 応動昆 25: 17-25.

Lima, S.L., WieBe, K.L. \& Dill, M., 1987. Protective cover and the use of space by finches: is closer better? Oikos 50: 225-230.

松岡茂, 1971. パイロットフォレストの鳥類相一秋期・冬期一. 北方林業 23: 236-241.

松岡茂, 1977. 北海道大学苫小牧地方演習林における冬期間のフクロウの食性について. 北大演習林 研報 34: 161-174.

MatsuoKa. S., 1980. Pseudo warning call in titmice. Jap.J.Ornithol. 29: 87-90.

松岡茂, 1984. 異常寒波とツグミの越冬数. Strix 3:36-39.

松岡茂, 1994a. ヒヨドリの群れサイズと飛び立ち距離との関係 一飛び立ち距離に対する神経質な 個体の反応の影響評価一。目鳥学誌 43: 19-28. 
松岡茂, 1994b. 防風林からの距離によるヒヨドリのキャベッ食害率の变異. 日鳥学誌 43: 101-103. MatsuoKa. S. \& KojIma, K. 1979. Winter food habits of grey-headed green woodpeckers Picus canus. Jap. J. Ornithol. 28: 107-116.

MoRSE, D.H., 1973. Interactions between tit flocks and sparrowhawks Accipiter nisus. Ibis 115: 591-593.

中田圭亮・田中悦夫・開本孝昭, 1985. エゾャチネズミの数と防除と被害. 一檜山地方一般民有林野 統計資料加ら一. 森林保護 No. 186: 10-11.

農林水産省農産園芸局植物防疫課， 1975 . 昭和49年度鳥類による農作物に対する被害.

農林水産省農産園芸局植物防疫課, 1984. 鳥獣類による農作物に対する被害調查概要. 植物防疫 38 : 491-494.

S A S インスティチュートジャパン, 1992. SAS Training 回帰分析コース. pp. 55 東京（株） SASインスティチュートジャパン.

SCHNEIDER, K.J., 1984. Dominance, predation, and optimal foraging in white-throated sparrow flocks. Ecology 65: 1820-1827.

Wilson, E.O., 1975. Sociobiology. London, Belknap Press.

（1995 年 1 月 10 日受理） 